Article

\title{
Monitoring Viability and Sustainability in Healthcare Organizations
}

\author{
Marialuisa Saviano ${ }^{1}$, Clara Bassano ${ }^{2, *}$, Paolo Piciocchi ${ }^{3}$, Primiano Di Nauta ${ }^{4, *}$ (i) and \\ Mattia Lettieri ${ }^{5}$ \\ 1 Department of Pharmacy and Pharmanomics Interdepartmental Center, University of Salerno, \\ 84084 Salerno, Italy; msaviano@unisa.it \\ 2 Department of Management Studies and Quantitative Methods, "Parthenope" University of Naples, \\ 80132 Naples, Italy \\ 3 Department of Political, Social and Communication Studies, University of Salerno, 84084 Salerno, Italy; \\ p.piciocchi@unisa.it \\ 4 Department of Economics, University of Foggia, 71121 Foggia, Italy \\ 5 Unipegaso, 80132 Naples, Italy; mattia.lettieri@unipegaso.it \\ * Correspondence: clara.bassano@uniparthenope.it (C.B.); primiano.dinauta@unifg.it (P.D.N.); \\ Tel.: +39-339-692-2328 (C.B.); +39-088-178-1712 (P.D.N.)
}

Received: 23 August 2018; Accepted: 29 September 2018; Published: 3 October 2018

check for updates

\begin{abstract}
The paper aims to advocate the incorporating of the sustainability perspective into the management control system of healthcare organizations. The study is based on two main premises: (1) the evolution of business models towards a wide perspective of the sustainability approach; (2) the evolution of control systems in healthcare organizations towards a control-based approach to monitor the effectiveness and efficiency of the service targeted primarily to cut costs and expenses. Our methodology is developed at theoretical and conceptual level starting from: (1) a literature review on the issue, highlighting main trends and gaps and (2) the adoption of the Viable Systems Approach (VSA) as a conceptual framework oriented to integrate a wide variety of stakeholder perspectives and interests into the business model. Our findings lead us to introduce the Systems Viability Monitoring Model for Sustainability as a potential reference framework to build healthcare management control systems in which the notion of 'systems viability,' as defined by VSA, becomes a bridging concept by means of which the sustainability perspective can be incorporated into the management control system of healthcare organizations.
\end{abstract}

Keywords: healthcare organizations; control; viability; sustainability; systems monitoring

\section{Introduction}

In recent decades, the management of healthcare organizations has been characterized by the progressive establishment of reductionist paradigms in which attention to the rationalization of resources and the maximization of performance has shifted, through the formalization of procedures, codes and protocols, towards an increasing focus on technical and economic performance. This pathway has had significant repercussions impacting, on the one hand, on the ethical-value dimension of the relationship with the healthcare user [1] and, on the other hand, on the overall healthcare management approach, ever more focused on finding conditions of economic equilibrium at local level. In fact, the current state of the organization-user relationship in healthcare highlights how the process of corporatization may be associated with lesser attention to the humanization of the service, plus an increase in the costs of benefits for citizens [2]. On the other hand, focus on the local level leads to adopt a reductionist view that is traditionally in contrast with health as one of the 
most important public goods requiring the adoption of a wider systems view [3-8]. Clearly, healthcare organizations are characterized by significant peculiarities both as concerns the public nature of their business and, above all, their delicate nature, that is, subject healthcare. This requires in the first instance, particular attention to the relationship with the user-going beyond the strictly technical element of performance and adopting a wider vision that rediscovers the ethics of a relationship based above all on values. Attention to the relationship with other relevant stakeholders is also fundamental whereby the conditions of equilibrium and long-term survival of the system depend.

Economic and managerial logics, especially in the Italian healthcare context [9-12], have been interpreted mainly as a way to achieve cost reduction especially through standardization, pre-prepared prescriptions and with the conviction of finding optimal solutions for every problem [13], often ending by subordinating the organization to the rules of economy and technology rather than the techniques to the rules of the organization [1].

Following the dominant approach to the management of healthcare, the definition of control systems in healthcare organizations has been influenced by the need to satisfy the expectations of the most relevant 'supra-systems,' that is, stakeholders that own the most critical resources and that are capable of exerting strong influence on the local system's decision makers [14], typically the policy makers whose priority, besides providing effective healthcare service, is to reduce public expense.

Parallel to this scenario, in the managerial and economic context, the evolution of business models has progressively led to extend the dominant focus onto the local economic as well as financial performance within a wider view that includes a variety of perspectives and interests associated to stakeholders that do not always own critical resources or have power of influence [14,15] but that can determine the conditions of long-term survival of the business. A paradigmatic change is starting to revolutionize the way healthcare organizations, as well as other social organizations, are conceived and managed and becoming more sustainable and inclusive [3,16-21].

Compared to businesses, healthcare organizations inevitably have a dual function. On the one hand, they deal with 'health' one of the most important sectors of public interest for all populations, hence, independently of the governance systems adopted in the country, effectiveness of service is the main priority; on the other, they work just like any other kind of organization that has to achieve monetary, financial and economic equilibrium to survive. Over time, due to the general scarcity of resources and to the relevant role of policy makers, this latter requirement has exerted growing pressure influencing the management approach on the part of healthcare organizations and, subsequently, their approach to control [22-26]. As for any other organization, the challenge is to reconcile the need to ensure local economic performance with socially and environmentally sustainable performance $[27,28]$. Such challenge, that in the context of healthcare can supposedly be taken at least in 'cultural' terms for granted, can be just as problematic as in any other organization, especially taking into account pressures to cut costs.

On the basis of the above, the aim of the paper is to re-examine the management control system in healthcare organizations in order to align its evolutionary trends to the current requirements of a sustainable and more inclusive approach. The focus should be extended from local economic and cost performance to the overall social and environmental impact of the organization in order to incorporate all the dimensions of sustainability in the management and control approach. In this respect, we believe that a sharper focus on sustainability would also lead to major improvements in performance, as opposed to cost-cutting, implying a shift from a pure spending review logic to one intrinsically oriented to optimise the use of resources. Thus, improved efficiency would be obtained not so much by cutting costs but by increasing productivity.

Given that as part of the reviewing process of the National Health Care System (NHCS) in Italy, healthcare organizations have put in place a managerial approach $[10,12]$, a subsequent necessity would be to adapt the information and accounting systems [29]. In our perspective, an adjustment process, mainly instrumental to the efficiency and effectiveness of decision making and subsequent action, has to include a sustainability perspective in order to shift from a short to a long-term view 
ensuring long term organizational viability and survival. This has to occur in co-evolution with their overall context from which they derive all the required resources for effective functioning.

Accordingly, a specific purpose of this paper is to highlight the need to provide the healthcare sector with tools for solving the problem of allocation of management costs, planning efficiency, control of health expenditure and the management and procurement of financial resources, within a logic of overall improvement and effectiveness of services provided and sustainability of the healthcare organizations and of the national healthcare system as a whole [30].

The paper is organized as follows: after this Introduction, Section 2 illustrates our methodological approach describing the tool used for the literature review and giving a detailed description of main elements of the interpretative perspective of the VSA; Section 3 presents the results of our study illustrating findings emerging from the literature review and introducing the Systems Viability Monitoring Model for Sustainability; Section 4 discusses how, from a VSA perspective, the notion of 'systems viability' becomes the bridging concept to incorporate the sustainability perspective within the management control system of healthcare organizations; Section 5 sets out our main conclusions and discusses future implications for research and the limits of the study.

\section{Materials and Methods}

In this section, we illustrate our methodological approach describing both the tool used for the literature review and the interpretative perspective of the VSA.

\subsection{The VOSviewer Software for the Literature Review}

One of the main methodological problems concerns the identification of a comprehensive literature on management control systems in healthcare organizations. To better understand main trends and gaps to narrow, a literature review was put in place using the software VOSviewer, a tool for constructing and visualizing bibliometric networks. These networks include journals, research, or individual publications and can be constructed based on citation, bibliographic coupling, co-citation, or co-authorship relations.

For our study, at a preliminary stage, data were exported by Scopus (Elsevier, Amsterdam, The Netherlands) exploring the literature by means of a specific query: TITL-ABS-KEY ("management control" AND "healthcare").

Subsequently, before explaining our view, a further query-TITL-ABS-KEY: ("sutainab*"AND "healthcare")—was inserted in Scopus, to search for works that would include a sustainability perspective in healthcare, our aim being to incorporate sustainability in management control. VOSviewer also offers text mining functions to construct and visualize co-occurrence networks of important terms extracted from a corpus of scientific literature. However, as we will show in Section 3, a bibliographic analysis was only carried out.

\subsection{The Interpretative Contribution of VSA}

In this section, we discuss the interpretative contribution of VSA [14,15,31-39] for purposes of clarification. Management needs to embrace a wider rather than traditional view of its context in order to interpret, evaluate and satisfy the expectations of a wider variety of stakeholders $[32,40]$ and should account to them for their behaviour. This requirement is at the basis of our aim to develop an integrated control system or systems monitoring for the viability and sustainability of the healthcare organizations.

VSA as a systems methodology useful for the investigation and governance of social organizations, highlights, in our view, several criticalities of the observed scenario, opening towards interesting interpretative hypotheses of the decision-action processes and, therefore, the concepts of responsibility and accountability of healthcare organizations. In other words, an interpretative methodology that shifts focus from the technical level of organizational functioning to more general interpretation 
schemes [35,36] as a basis for approaching decision making and problem-solving in complex contexts [41].

\subsubsection{The Relevance of Context in The Relational Dynamics of the Viable System}

One of the main interpretative contributions offered by VSA is in having shifted the attention from the company (systemic entity under focus), observed and described as an objective entity (focus on the structure: 'how it is made'), to the company as an actor responsible for the dynamics developed in the context in which it operates (focus on the system: 'how it behaves') [36].

The traditional interpretation of the relationship between business and the environment is thus re-examined by accentuating the point of view of the decision-maker who identifies in the environment all the interlocutors with whom to relate, thus defining their own viable context [42,43]. The assessment of the relevance of each interlocutor with respect to the objectives pursued by the company enables the decision maker to devise appropriate relational strategies. In VSA, the notion of context is a richer and more significant concept compared to that of environment: the context is made up not simply of generic stakeholders but of specific actors (viable systems) that have specific expectations relative to the stake they hold and are capable of exerting power of influence and of controlling access to resources critical for the system under focus, so becoming 'supra-systems.' Therefore, it is on the context that attention must be focused in order to ascertain how sustainability, which is a multi-dimensional and multi-perspective expectation to comply with, can be achieved. The shift of focus onto context implies the recognition of a priority in terms of collective interests, accepted and shared on the basis of the dominant values system, with respect to individual ones. Consequently, the decision maker must concentrate on how the systemic entity governed can align its interests with those of the supra-systems context in which it operates, seeking a role to play within it as a useful, if not essential, component for the balanced functioning of the context as an ecosystem [44,45].

Thus, it is clear that the survival of the system, as part of a whole, is linked to the survival of the whole. Furthermore, it is clear that the condition of ecosystem equilibrium is linked to the harmonious interaction between the parties, the viable dynamic of which is not only sustainable but actively contributes to the harmony of the whole. In short, a system is viable if it is able to dynamically survive in an (eco)systemic context with a role that connects it effectively with the other entities with which it interacts, harmoniously reconciling mutual goals and expectations [46].

The harmonious connection with the context refers to an assessment of alignment of the processes of the organization with the series of laws and rules accepted and shared by the community, which, in turn, reflects the dominant values system. In other words, the behaviour of the organization reflects specific context conditions, which vary in time and space, characterizing different scenarios.

\subsubsection{Viability in the VSA Framework}

In the VSA perspective, systems are qualified as viable as they are oriented towards the ultimate goal of survival [47]. Fundamental for survival purposes is the search for harmonic relationships (consonance) in its context of action. The consonance orientation, in only apparent antithesis to the traditional orientation towards competitiveness, is central to the VSA framework.

The viable system creates its conditions of survival in the context, establishing harmonious relations with other entities that populate it. The effectiveness and solidity of these relationships depend on the ability of the system to meet the expectations of the various interlocutors/stakeholders, seen as supra-systems and to derive guidelines and rules of conduct $[14,35,48,49]$. By virtue of an evaluation of relevance, based on the criticality of the resource released by the supra-system and on the capacity of influence that the latter can exercise on the system, the government of the system defines the consonant conditions necessary for harmonious development of the relationship, adjusting its relational strategy and controlling the impact of its action in the context. For governing and managing relations with the different interlocutors of the viable system, the consonance orientation overcomes the traditional negotiation perspective, typically transactional and inspired by short-term benefits [50]. 
In inter-system relations, consonance, in fact, directs the decision-maker towards the sharing of values and principles, trying to harmonize their goals with those of the relevant supra-systems and thus creating the conditions for harmonious interaction. Lasting harmony is, therefore, based on a balanced representation of the interests and needs at stake beyond the short-term space-temporal horizon. It is, therefore, through consonance that the passage of sustainability from the philosophical level, or of the basic principles, to that of concreteness, of operations, is achieved [51].

In the methodological framework of VSA [14,52], two aspects are particularly relevant from a management and control perspective:

- contextualization of the analysis by the recovery of the necessary variety both in terms of inter-system control (relationships with the stakeholders and/or the supra-systems) and in terms of operative structure control.

- $\quad$ subjectivity and, therefore, the uniqueness of the management and control systems calibrated on the specific structure/system managed;

VSA provides a useful framework that identifies the critical levels of the decision/action/control process, distinguishing between the notions of business idea, logical structure, actual structure, extended structure and specific structure, as follows (Figure 1):

- Business idea: representation of distinctive organization's lines;

- Logical Structure: representation of the logical components meant to perform a specific role;

- Actual structure: representation of the physical components with the underlying capability based on a more or less determined elementary character;

- Extended structure: representation of the physical components and the connections between them and with the components of external entities;

- Specific structure: representation of the set of skills that the system uses for its dynamic evolution.

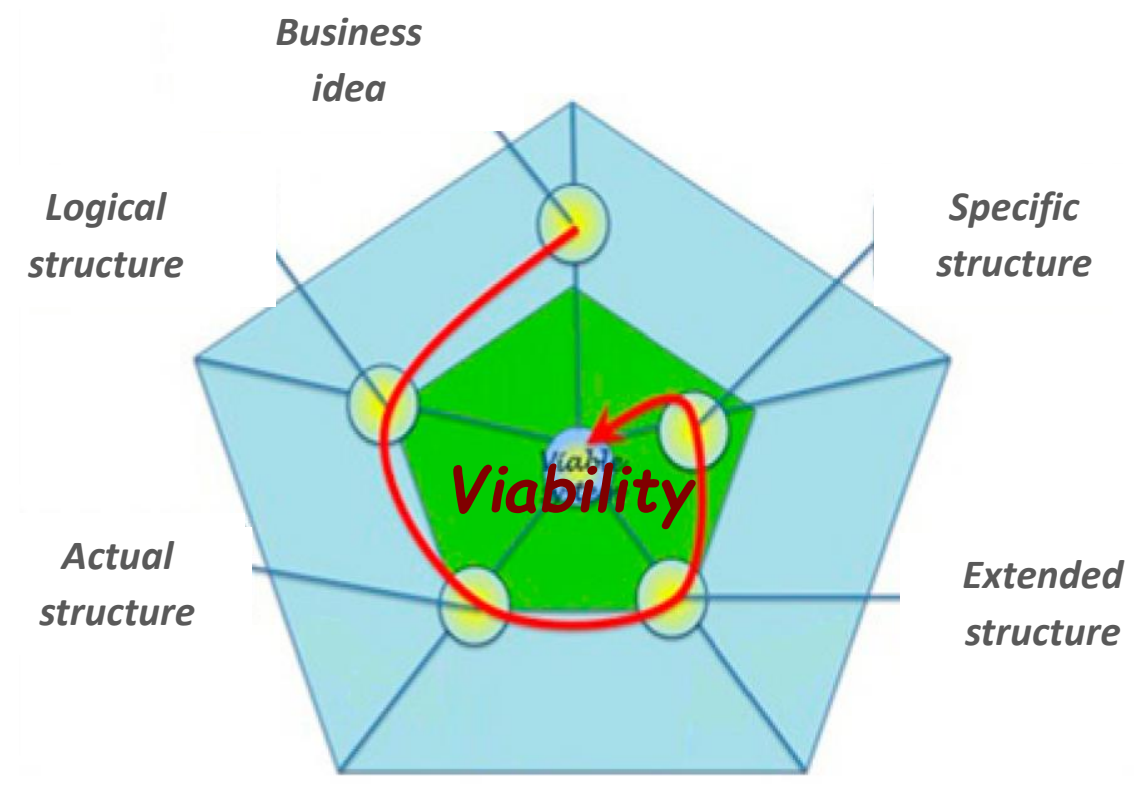

Figure 1. The VSA conceptual framework for decision/action/control (Source: Elaboration from [53,54]).

This framework is the basis for defining the management and control system through which the functioning of the system is analysed, planned, realized, monitored and controlled to ensure the viability of the system. In our perspective, which focuses on the dynamic aspects of organizational functioning, monitoring refers to the process of watching, keeping track of and gathering data about performance while control refers to the process of actively exercising power over, guiding 
and supervising behaviour, tasks and activities in a business or organization [52]. Control can include the setting up a system, procedures and policies to guide and regulate work processes. In other words, a system to influence behaviours and activities that actively monitors and adjusts. Monitoring does not necessarily involve control, or it can refer to monitoring as a part of control. In the VSA perspective smart governance requires both monitoring and control: while monitoring is useful to guarantee the homeostasis processes of the system in a particular context (system efficiency), control results from the adapting of the embedded processes (system efficacy).

\subsubsection{Sustainability in the VSA Framework}

Nowadays, in various forms and models, the common representation of the concept of sustainability pivots on three 'pillars': the environment, society and the economy [55-57]. The concept of sustainability with which traditional measures of wealth and economic growth based on GDP, however, have appeared inadequate to represent the welfare conditions of a country. A multi-perspective approach is required to study the behaviour of organizations that includes an ecological and social perspective in the traditional economic and financial vision of the accountability system. In such a vision, an organization considered sustainable is one that is not only stable economically but one which minimizes its negative environmental impacts and acts in accordance with social expectations, taking into account the responsibly towards future generations in terms not only of economic production but also ethical, ecological and social issues [51]. However, the signs of a profound cultural change destined to produce transformative effects of the current predominant models are evident, the implications of which are numerous, not entirely predictable and, in any case, not yet accepted by the majority. In this respect, a unitary vision of real phenomena should be recovered that takes into account the inviolable laws of nature that limit the spectrum of potential physical, technical and biological processes. The assessment of a process in terms of sustainability is based on a variety of interconnected elements, whose interactions, often emerging, must be taken into due consideration. In other words, the deterministic approach, based on the linear logic of cause and effect, still predominant in many areas of knowledge, should shift in the direction of a systems perspective capable of grasping the links between the parties within the whole, fostering a deeper awareness of the relationship between man and nature. Clearly, the current conditions of imbalance attribute the blame to the economy and the main actors responsible to business organizations. Scholars of business economics, therefore, are not exempt from the responsibility of contributing to the advancement of the knowledge and awareness necessary to meet the challenge of sustainability [58].

To this aim, we intend to formulate an interpretative proposal that offers a key in terms of the control of viability and sustainability of healthcare organizations, based on a systems perspective that implies monitoring the viability and sustainability of the organization not only to verify the effectiveness and efficiency of the service but also the overall sustainability of the governance system.

The viable system paradigm systematizes and formalizes an interpretative perspective consolidated in managerial sciences and proposes an evolutionary vision in which the managerial capacity of the organizations is expressed in management models that take into account and are able to link a broad and inclusive variety of interests [59]. Going beyond the perspective of Corporate Social Responsibility and the Stakeholder Theory [40], the viable system paradigm is proposed as an interpretative key for an evolutionary concept of organizations, where the focus of the analytical horizon shifts from economic and financial performance and the structure of the system (in which the conditions of economic-structural efficiency are realized), to a vision extended to the social context (in which the conditions of social effectiveness are realized) to include the broader perspective of the natural environment (in which the conditions of environmental sustainability are realized) (Figure 2).

The proposed interpretative framework prompts a reviewing of the objectives of the local economic-structural efficiency of healthcare organizations in terms of the needs of economic sustainability, those of systemic effectiveness, needs of social sustainability and those of the equilibrium of the ecosystem for environmental sustainability, thus bringing the three perspectives within a single 
and composite view of sustainability in order to rethink the management control system of healthcare organizations.

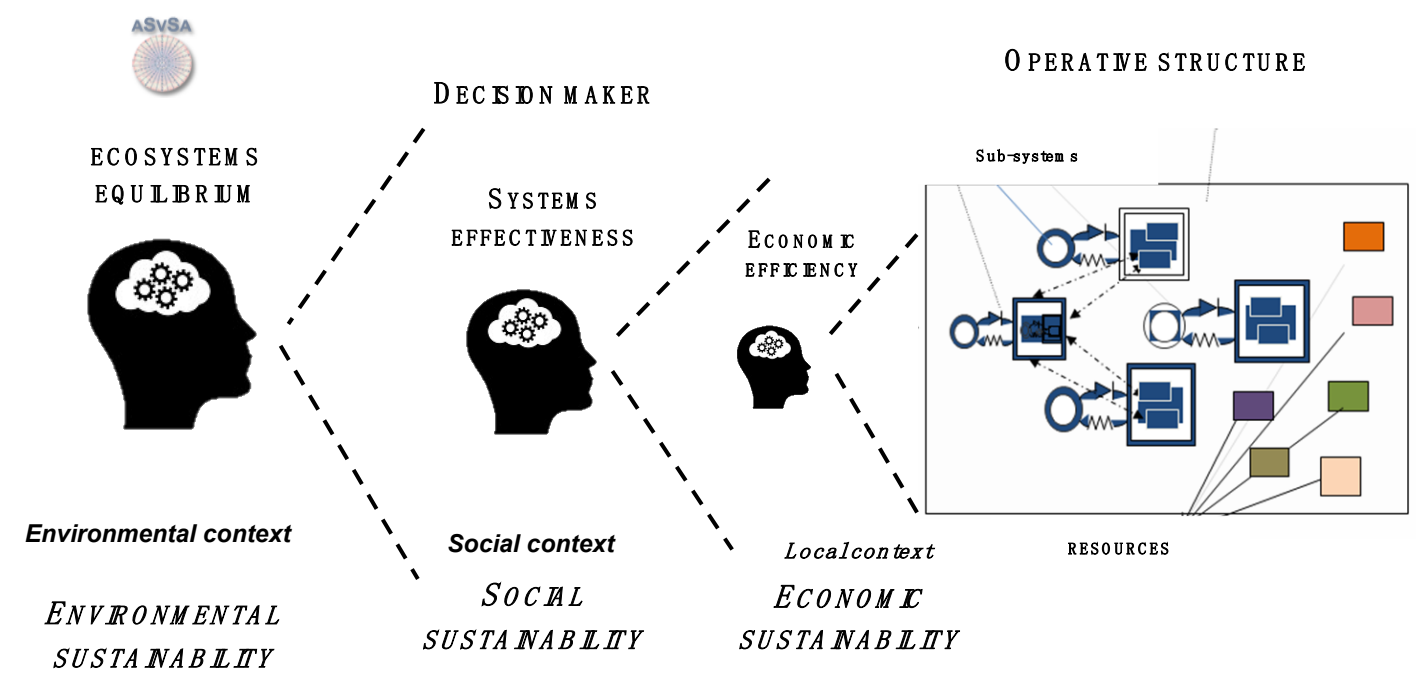

Figure 2. The overall view of sustainability in the management of viable systems (Source: $[54,60]$ ).

\section{Results}

Section 3 presents the results of our study illustrating findings emerging from the literature review, hence the need to rethink the control systems in healthcare organizations to incorporate sustainability and the necessity of a systems approach and introducing the Systems Viability Monitoring Model for Sustainability [61,62].

\subsection{Management Control in Healthcare Studies}

From the literature review in essence, it emerges that current studies on control are fragmentary and heterogeneous. The main Literature clusters on management control studies in healthcare were collected by adopting the VOSviewer software (version 1.6.9, Leiden University, Centre for Science and Technology, Leiden, Netherlands) as explained in Section 2.

For our study, data were exported by Scopus (Elsevier), the largest abstract and citation database of peer-reviewed literature; exploring the literature (every article from scientific journals, books and conference proceedings) through the query: TITL-ABS-KEY ("management control*" AND "healthcare") either in the title, in the abstract or from the keywords. The search came up with 77 documents and we decided not to limit our research to any specific subject area or source, preferring to use all the results indiscriminately (including "false positive," that is, papers in appearance related to the investigated question). We then exported the results, choosing to export all of the available information, in CSV (Excel) format. Subsequently, we used the software VOSviewer by Nees Jan van Eck and Ludo Waltman to create a map based on the bibliographic data obtained from Scopus. For this particular type of the analysis, we used the Bibliographic coupling model, fractional counting method and documents. The technique analyses the similarity between two documents, regrouping documents that have a third article in common in their bibliographies. The more articles are in common, the stronger the coupling between them [63]. We decided not to use a minimum number of citations threshold ( 0 in the box) choosing to consider all the 77 documents. The largest set of connected items consisted of 19 items from among the 77, so we chose to display this set of items instead. By displaying the largest set of connected items (19 of the 77 documents), the software identified clusters that represent a set of literature in the field of management control in healthcare studies.

Figure 3 represents 6 clusters that reveal different research objectives. The width of lines represents the strength of the relationship between nodes and the size of the nodes the number of citations. Table 1 contains articles grouped in clusters. 
Table 1. Clusters details.

\begin{tabular}{|c|c|c|c|c|}
\hline Cluster & Authors & Year & Title & Journal \\
\hline \multirow{4}{*}{1} & Waring, J. \& Currie, G. & 2009 & $\begin{array}{l}\text { Managing expert knowledge: organizational challenges and } \\
\text { managerial futures for the UK medical profession }\end{array}$ & Organization Studies, 30(7), 755-778 \\
\hline & Longo, F., Salvatore, D. \& Tasselli, S. & 2011 & $\begin{array}{l}\text { Are public health authorities able to "steer" rather than "row"? An } \\
\text { empirical analysis in the Italian National Health Service }\end{array}$ & $\begin{array}{c}\text { The International journal of health planning and } \\
\text { management, } 26(3), 319-333\end{array}$ \\
\hline & $\begin{array}{l}\text { Numerato, D., Salvatore, D., \& } \\
\text { Fattore, G. }\end{array}$ & 2012 & The impact of management on medical professionalism: a review & Sociology of health \& illness \\
\hline & $\begin{array}{l}\text { Kraus, K., Kennergren, C. \& von } \\
\text { Unge, A. }\end{array}$ & 2017 & $\begin{array}{l}\text { The interplay between ideological control and formal management } \\
\text { control systems-A case study of a non-governmental organisation. }\end{array}$ & Accounting, Organizations and Society, 63, 42-59. \\
\hline \multirow{4}{*}{2} & Beil-Hildebrand, M. B. & 2002 & $\begin{array}{l}\text { Theorising culture and culture in context: Institutional excellence and } \\
\text { control }\end{array}$ & Nursing Inquiry, 9(4), 257-274 \\
\hline & Houghton, F. & 2006 & $\begin{array}{l}\text { Reflection and comment: Health GIS in the mid-west: Unexpected } \\
\text { developments and directions }\end{array}$ & Irish geography, 39(1), pp. 99-104 \\
\hline & Cooke, H. & 2007 & $\begin{array}{c}\text { Out there, you're on a stage": complaints and the management of } \\
\text { emotion work in nursing. }\end{array}$ & $\begin{array}{l}\text { International Journal of Work Organisation and } \\
\text { Emotion, 2(2), } 145-160\end{array}$ \\
\hline & $\begin{array}{l}\text { Wise, S., Duffield, C., Fry, M., \& } \\
\text { Roche, M. }\end{array}$ & 2017 & Workforce flexibility-in defence of professional healthcare work. & $\begin{array}{l}\text { Journal of health organization and management, } \\
\text { 31(4), 503-516 }\end{array}$ \\
\hline \multirow{4}{*}{3} & $\begin{array}{l}\text { Monfardini, P., Ruggiero, P., } \\
\text { Gepponi, A. \& Barretta, D. }\end{array}$ & 2009 & $\begin{array}{l}\text { Inter-organizational management control in Health and Social Care: } \\
\text { An exploratory analysis of Healthcare Consortia in Tuscany. }\end{array}$ & Mecosan, 71, 85-98. \\
\hline & $\begin{array}{l}\text { Elg, M., Stenberg, J., Kammerlind, } \\
\text { P., Tullberg, S. \& Olsson, J. }\end{array}$ & 2011 & $\begin{array}{c}\text { Swedish healthcare management practices and quality improvement } \\
\text { work: development trends. }\end{array}$ & $\begin{array}{l}\text { International journal of health care quality } \\
\text { assurance, } 24(2), 101-123\end{array}$ \\
\hline & King, R., \& Clarkson, P. & 2015 & $\begin{array}{c}\text { Management control system design, ownership and performance in } \\
\text { professional service organisations. }\end{array}$ & Accounting, Organizations and Society, 45, 24-39. \\
\hline & Vaia, G., Bisogno, M. \& Bizzarri, G. & 2015 & $\begin{array}{l}\text { How to Drive Innovation Within Outsourcing Relations: The Role of } \\
\text { Performance Evaluation and Management Control Systems. }\end{array}$ & $\begin{array}{l}\text { International Workshop on Global Sourcing of } \\
\text { Information Technology and Business Processes, } \\
\text { (pp. 142-155). Springer, Cham. }\end{array}$ \\
\hline \multirow{3}{*}{4} & Naranjo G., D. & 2010 & $\begin{array}{l}\text { The use of the balanced scorecard and the budget in the strategic } \\
\text { management of public hospitals }\end{array}$ & Gaceta sanitaria, 24(3), 220-224 \\
\hline & $\begin{array}{l}\text { Naranjo G., D., Sánchez-Expósito, } \\
\text { M. J. \& Gómez-Ruiz, L. }\end{array}$ & 2016 & $\begin{array}{l}\text { Traditional vs. Contemporary management control practices for } \\
\text { developing public health policies. }\end{array}$ & $\begin{array}{l}\text { International journal of environmental research } \\
\text { and public health, } 13(7), 713\end{array}$ \\
\hline & $\begin{array}{l}\text { Lunkes, R. J., Naranjo G., D., \& } \\
\text { Lopez-Valeiras, E. }\end{array}$ & 2018 & $\begin{array}{l}\text { Management Control Systems and Clinical Experience of Managers } \\
\text { in Public Hospitals }\end{array}$ & $\begin{array}{l}\text { International journal of environmental research } \\
\text { and public health, 15(4), } 776\end{array}$ \\
\hline
\end{tabular}


Table 1. Cont.

\begin{tabular}{|c|c|c|c|c|}
\hline Cluster & Authors & Year & Title & Journal \\
\hline \multirow[t]{2}{*}{5} & Morelli, M. \& Lecci, F. & 2011 & $\begin{array}{l}\text { Governo dei costi e cambiamento aziendale. La lunga strada verso } \\
\text { l'integrazione. }\end{array}$ & Mecosan, 20(80), 59-75 \\
\hline & Morelli, M. \& Lecci, F. & 2014 & $\begin{array}{l}\text { Management control systems (MCS) change and the impact of top } \\
\text { management characteristics: the case of healthcare organisations }\end{array}$ & Journal of Management Control, 24(3), 267-298 \\
\hline \multirow[t]{2}{*}{6} & $\begin{array}{l}\text { Willemstein P., van der Ven M. \& } \\
\text { Versendaal J. }\end{array}$ & 2014 & $\begin{array}{l}\text { Professionalizing management accounting and control at small } \\
\text { healthcare organizations: a case study }\end{array}$ & $\begin{array}{l}\text { Proceedings of the 7th iadis international } \\
\text { conference information systems, IS } 2014 \\
\text { pp. 51-58 }\end{array}$ \\
\hline & Rouhana, R. \& Van Caillie, D. & 2016 & $\begin{array}{l}\text { The design of performance monitoring systems in healthcare } \\
\text { organizations: a stakeholder perspective }\end{array}$ & Journal Medical Libanais, 64, 270-279 \\
\hline
\end{tabular}

Cluster 1: addresses organizational matters and managerial implications. In detail, Waring and Currie [64] and Numerato et al. [65] deal with management and profe Longo et al. [66] with ineffective control systems by public health authorities and Kraus et al. [67] with organizational identity and organizational ideology as essential dimensions of management control systems; Cluster 2: includes papers on new forms of control in healthcare organization, such as culture [68] or consumer feedback as a management control strategy [69]; new tools of control such as Geographical information systems (GIS) [70] or work flexibility to control cost and healthcare remits [71]; Cluster 3: regroups observation on control in collaboration management practice. Monfardini et al. [72] investigate on control mechanisms in inter-organizational relationships; Elg et al. [73] on control mechanism of organizational activities that involve patients, managers and politicians; Vaia et al. [74] on control in outsourcing relationship e King and Clarkson [75] on interplay between ownership and management control systems; Cluster 4: reflects on models and techniques of management control to facilitate strategic management. Lunkes et al. [76] analyse the positive effects of horizontal control management on operational performance; Naranjo et al. [77] compare traditional control models (based on coercive practice) and contemporary models (based on enabling practices) to manage control in healthcare organizations; Naranjo [78] proposes the balanced scorecard technique to provide financial and non-financial information useful to impact on operational and strategic aspects; Cluster 5: focuses on control process and change. Morelli and Lecci [79] study changes in control systems and effects in business changes, adding to a cost analysis, an analysis of environmental, institutional and governmental variables. Morelli and Lecci [80] analyse in depth change in management control systems (MCS) and the impact of top manalysis of environmental, institutional and governmental variables. Morelli and Lecci [80] analyse in depth change in management control systems (MCS) and the impact of top while Rouhana and Van Caillie [82] propose a stakeholder perspective for monitoring systems in healthcare organizations. 


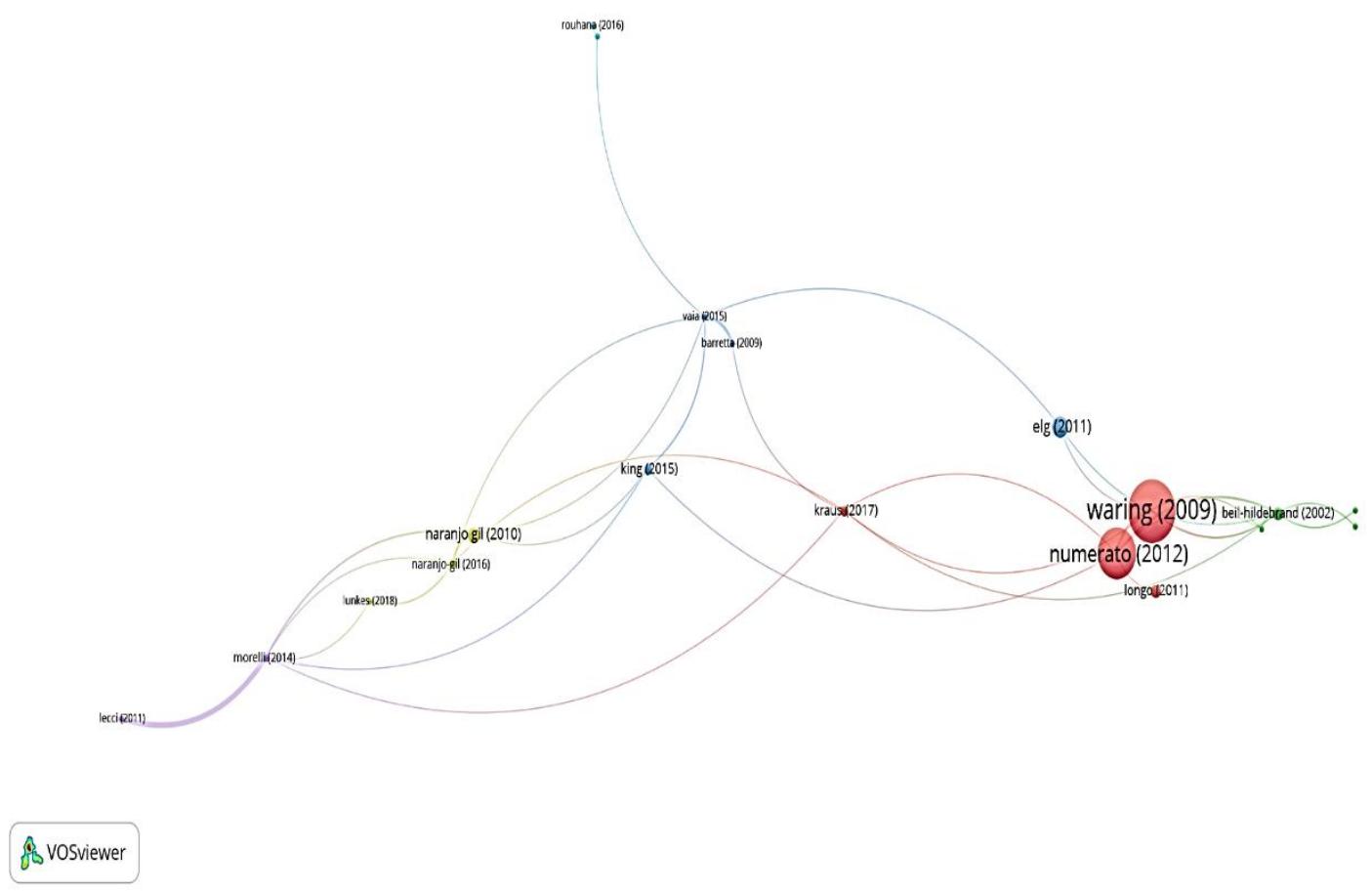

Figure 3. VOSviewer visualization (for document) using the bibliographic coupling technique.

As shown in Figure 3 and Table 1, a large proportion of literature links control with economic performance; however, some studies mention other aspects, crosscutting the economic [66,67,81] and Tayloristic [71] view-proposing models and control tools that consider external or non-financial variables [76,78].

\subsection{The Need to Incorporate Sustainability into Management Control}

Despite the willingness to embrace new perspectives, the concept of control and that of sustainability in healthcare systems do not seem significantly related: in 19 analysed works of the 79 collected there are no points on sustainability. A literature gap clearly emerges.

Consequently, we decided to continue the study searching for articles that contained both the terms "sustainability" (using the query "sustainab*" on Scopus not to exclude any result) and "healthcare," so our research query appeared like this: (TITLE-ABS-KEY ("sustainab*") AND TITLE-ABS-KEY ("healthcare").

Results, initially, were huge: 5160 papers in several disciplinary areas. Therefore, to make the analysis consistent with our research purpose, we restricted the selection criteria to "Business, Management and Accounting" and "Health professional" areas downsizing our results to 638, sorted on relevance. We then exported the results in CSV as before and proceeded to create a map using the same methods of analysis we used to obtain the first map. The significant number of outcomes confirms the importance of associating both healthcare and sustainability studies. The multiplicity of studies and disciplines involved in the debate, however, focus alternately on diverse and singular aspects, disregarding the holistic vision of the phenomenon. Some studies concern sustainability in organizational change [22], other in financial sustainability [23], including even architectural sustainability [83]. Figure 4 shows the effective size of documents and the 23 clusters obtained by the bibliographic coupling from the previous query. This, confirms the Authors' preference to refer the analysis to works with greater weight in terms of citation thanks to cluster size. 


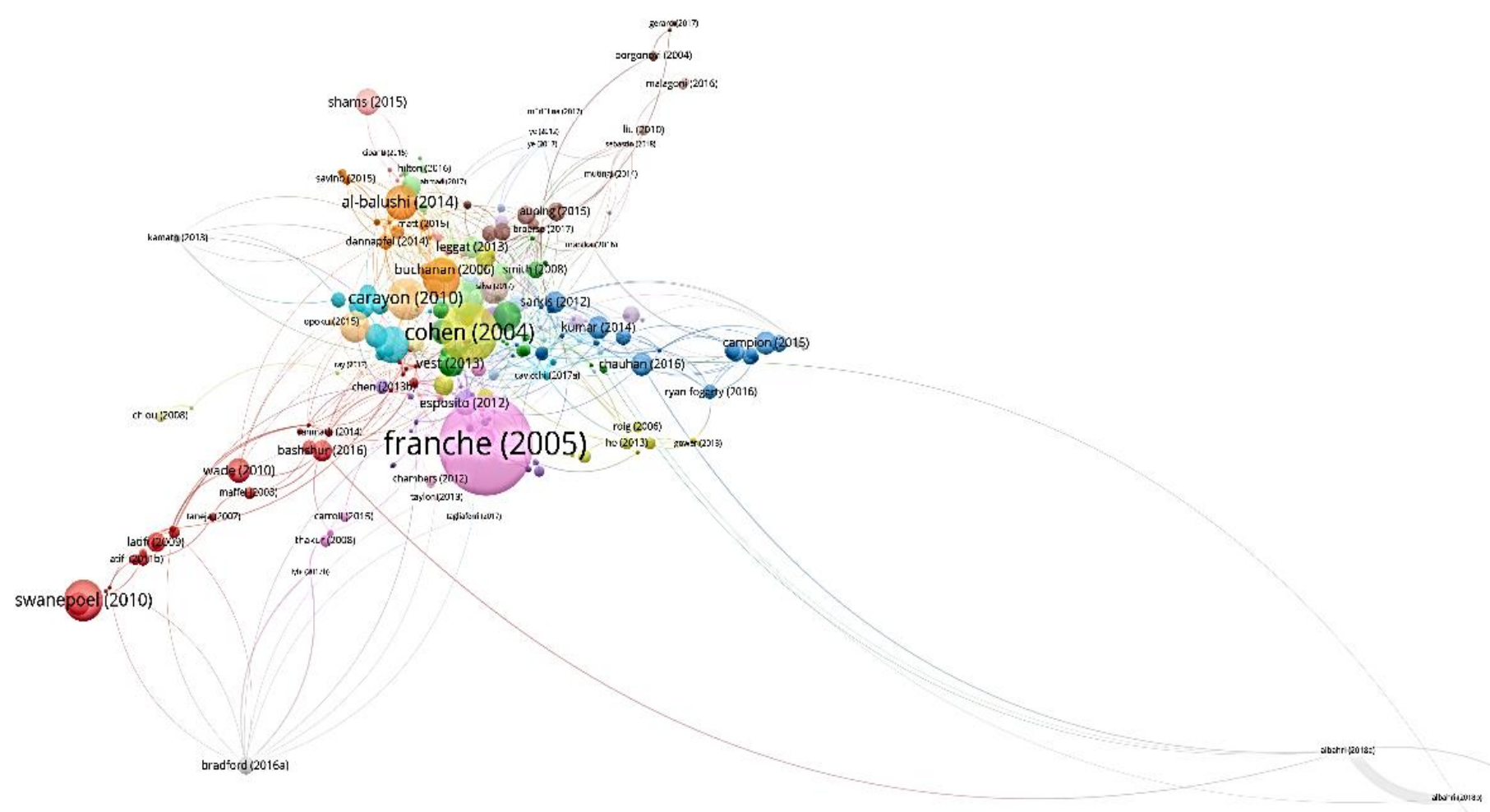

\section{Anvoswiewer}

Figure 4. VOSviewer visualization (for document) using the bibliographic coupling technique on TITL- ABS-KEY: ("sustainab*" AND “healthcare"). 
The term "sustainability" deriving from the adjective "sustainable" frequently appears applied superficially. In healthcare, the word is mainly associated to cost reduction of product, services [84] or human resources [25], rarely, employed in other issues such as healthcare practices [24] or innovation [26]. In our opinion, a new and clearer vision of these concepts in the definition of the management and control systems should be worked on.

\subsection{Incorporating Sustainability into the Management System}

In VSA, the concept of sustainability results strictly linked to that of viability [3] and represents the cementing between the viability itself of the system (the being-identity) and its survival (the becoming in co-evolution in the context). The perspective of sustainability, in fact, directs the decision maker to evaluate the strategic options that enable the system to enhance its role in context due to the co-evolutionary choices of the economic, social and environmental context in which the system 'is' and 'becomes.'

The following Figure 5 represents, in a conceptual way, the relationship between viability, sustainability and survival according to the different configurations of the structure of a viable system as proposed by the VSA decision/action/control framework [14,36].
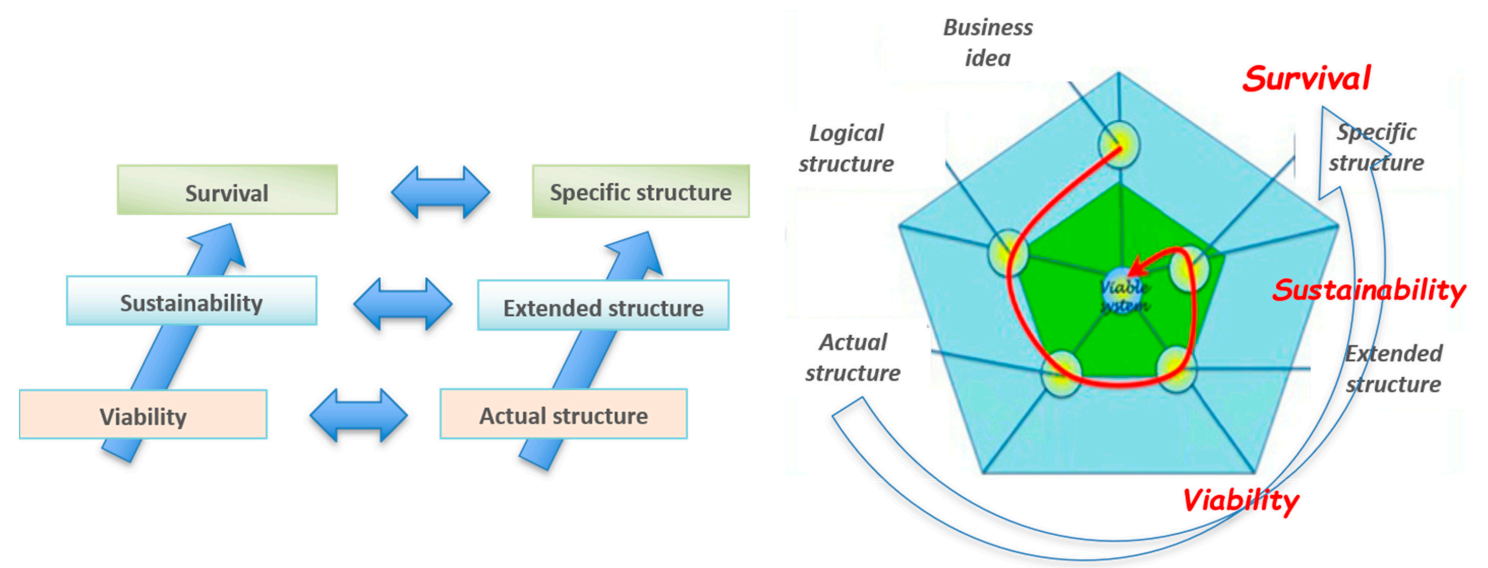

Figure 5. Relationship between viability, sustainability and survival according the decision/action/ control framework of VSA (Source: [54]).

From the Figure, we evince that the actual structure of the system is the necessary condition for framing system viability (viable identity) but not sufficient to qualify the sustainable viability (viability in the context) of the system itself that refers, instead, to the configuration of the system's extended structure. However, sustainable viability is not a sufficient condition for determining the purpose of the system, that is, the survival of the system (co-evolution system-context) that is, the evolutionary degree of viable identity projected over time and deriving from the monitoring of viability and the evolutionary optimization process. The goal of harmonic interaction between the areas of the economy, society and environment enables us to determine the dynamic evolution of the system within its context (viability and being) and how, through the field forces of mutual interaction between organization and environment, the survival of the system is able, in turn, to generate new contexts and new sustainable options (co-evolution system-context).

\subsection{Incorporating Sustainability into the Control System: The Systems Viability Monitoring Model for Sustainability}

Within the context of the healthcare system, the conditions of harmony between ethical and rational behaviour are recomposed within the model of the viable system, in which "the institutional government is responsible for the survival of an organization, taking its aims, rules and constraints from the context in order to successfully conduct the operative structure, responsible for the efficiency of the system" [30] (p.3). 
In this sense, in sustainable healthcare organizations, the systems equilibrium process has a recursive and circular nature. It is a process of co-evolution system-context in the continuum of viability and is aimed at the optimization over time of the ability to survive in the face of changes induced by the context but also because of context changes in terms of perception by effect of the reciprocal influences with the system itself.

Thus, in organization(al) survival, understood as a systemic aim, the necessary and sufficient conditions for the emergence of sustainable healthcare systems are incorporated; in other words, if viability represents the system's long-term aim and if sustainability refers to the "adaptive behaviour" of the system itself, then survival qualifies, in a co-evolutionary system/context, the ability to respond adequately to the expectations of relevant entities of the context.

In order, to incorporate sustainability into the control system, the starting point is to verify whether and how a control system inspired by the VSA conceptual framework can enable an acceptable normalization/adaptation of the activities and results of healthcare organizations for sustainability. In adherence with the VSA view of sustainability, considering the health structures as open systems that interact in a context of "supra-systems," the sustainability target becomes ever more relevant $[3,14,53]$. Subsequently, within this logic, a systems control is required that monitors the relational dynamics of the organization under focus. This form of control, therefore, which we define as of an inter-systems type, is directly pertinent to the government (decision maker), which, in order to respond to the systems purpose of the structure, is obliged to go beyond mere verification of the suitability of the services. However, if it is true that the supra-systems exert pressure and project differentiated expectations onto the healthcare system - in its different structural configurations-the effectiveness and efficiency of control depend on the ability of government to monitor the critical bearing of resources and the influence of the supra-systems [14]. Specifically, according to the conceptual framework we adopt, the effectiveness of the control on the part of the supra-systems on the health organization depends on:

- the level of complexity of the healthcare organization, in the sense that the more complex the organization, the more opaque it will appear compared to the external environment and the less controllable, highlighting greater levels of information asymmetries;

- the problems of freeriding or divergence between private and public benefits. This means that for the individual user, the costs associated with control activities will exceed the benefits. Moreover, this kind of control depends on the particular organization of the supra-system: the more the system is embryonal (not yet viable) the more these freeriding problems appear evident; while the more the system is viable, the less problematic the areas appear.

In particular, where it is possible to arrive at an integrated control system in healthcare organizations, it is necessary to verify its effective implementation taking into account that the systems methodological approach tends to privilege and highlight two important aspects linked to viability and the survival of organizations: government and management of the company, be it public or private [85].

Both elements tend to focus the attention of the research onto two logical levels of analysis [53]:

- $\quad$ structure;

- system.

It seems clear, therefore, that such an approach tends to qualify the control activity of health care organizations through two essential moments by means of which the emerging healthcare service system is detected:

- $\quad$ the adequacy check of components and relationships (structure control);

- performance control (system control).

In the following figure, the viability control of a healthcare system, according to VSA can be qualified. In the figure, four areas of control are highlighted whereby it is possible to configure the monitoring of viability of a viable business system — and therefore also of a healthcare organization —and to verify the efficiency and efficacy of government. 
In particular, as shown in Figure 6, we identify [61,62]:

- inter-system control ( $\left.\mathrm{Cl}^{\prime} \mathrm{a}\right)$, that is, monitoring of the relations between government of the L system and government of the $\mathrm{L}+1$ system (supra-systems);

- operative structure control $\left(\mathrm{C}^{\prime} \mathrm{b}\right)$, that is, monitoring of the relations between government of the $\mathrm{L}$ system and its operative structure;

- operative control of type $1\left(\mathrm{C} 2^{\prime} \mathrm{a}\right)$, that is, monitoring the relationships between various components of the actual structure of the $\mathrm{L}$ system and components of the actual structure of the $\mathrm{L}+1$ system;

- operative control of type $2\left(\mathrm{C} 2^{\prime} \mathrm{b}\right)$, that is, monitoring of the components of the operative structure of the L system.

- In particular, within the system control, there is a difference between:

- Inter-system control of the organization in order to define the conditions of consonance of the extended structure with the various supra-systems that first influence, then legitimize and justify the existence of any health service organization.

- Operative structure control of the selected structure appointed to implement the conditions of consonance and to verify the performance, not only and exclusively, of the service provided.

According to the VSA view, it is at the level of the inter-systems control that the monitoring of viability must be integrated with the variable of sustainability, which is the level of the extended structure where the effective outcome of the relational strategy with the context are determined.

This suggests that VSA should work on developing a formal approach in order to harmonically incorporate a sustainability perspective into the management/control system of the organization by:

1. reviewing conditions for the efficiency of the local organizational structure at operative level, in terms of economic sustainability;

2. reviewing conditions for the effectiveness of the service as capability to respond to the various and multiple needs of the community also in terms of social sustainability, with wider attention to overall health conditions from the internal (operative structure level) to the external context (inter-system level) of the territory;

3. introducing an evaluation of the overall conditions for eco-system equilibrium of the managed organization in terms of environmental sustainability including an ecological perspective.

As far as structural control is concerned, the focus pivots on the structural elements, that is, on the verification of the adequacy of the components and relationships. In particular, the structural elements are in turn made up of both an organizational and technical component. The organizational component of management control regards the breaking up of the organization into objects of a lower order so that it is possible to define objectives, monitoring and assessment for "areas of responsibility" and/or "areas of results."

The technical component regards the instruments used to represent the organization's dynamics or its specific operating combinations. Reference is usually to the accounting matrix tools:

- general accounting,

- analytical accounting,

- budget,

- $\quad$ reporting system,

- $\quad$ variance analysis system.

However, these instruments are limited to the economic measurement of some management events while nothing indicates other events that do not produce an immediate economic consequence. Moreover, the use of such instruments, at least in their classical form, appears to be too oriented to the measurement of economic-financial performance, not entirely in line with the institutional purpose of healthcare organizations that must be aligned to sustainability requirements. Therefore, besides the above, tools for measuring non-quantitative aspects are also required. 


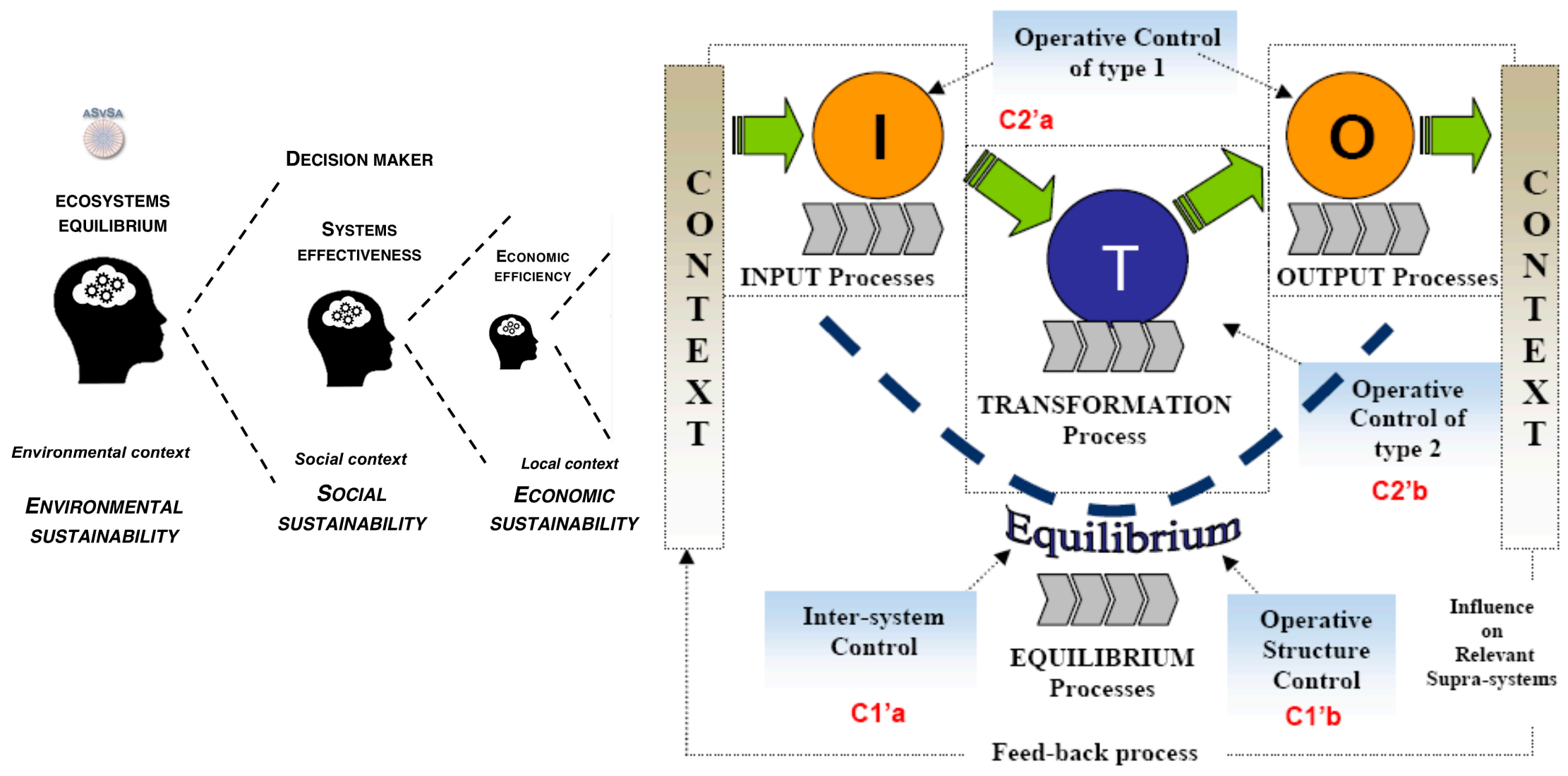

Figure 6. The Systems Viability Monitoring Model for Sustainability (Source: Elaboration from: [54,60-62]). 


\section{Discussions}

Discussion, in Section 4, clarifies that from a VSA perspective, the notion of 'systems viability' becomes the bridging concept to reconcile the effectiveness and efficiency of service within an overall view of sustainability [86].

Healthcare organizations carry out a variety of activities that are combined in diverse operational processes, finding their productive purpose and mission not only in meeting the needs of individual patients but also in ensuring the overall well-being of populations. Hence, incorporating sustainability into the management and control system is fundamental and also useful in the pursuit of change and innovation.

In sum, incorporating sustainability into the control system implies that the management system is not only focused on the local performance of the structure but also extended to effective management of the healthcare environment, the social dimension of the service provider-client interaction, community-based healthcare approaches and so forth. In this view, also traditional problems such as - the most relevant-the humanization of healthcare, find a re-motivating emphasis and show all their relevance for the long-term viable survival of the organization in its context.

Although the logical pathway to incorporating sustainability in healthcare organizations, would appear to be adapting management rather than the control system, in our opinion, besides revising the control system, as in the view of VSA, introducing an overall systems perspective, would encourage a general re-thinking of the management approach at a more practical level, given the greater difficulty of changing minds as opposed to action. The dominant focus on cost performance and the accepted systems of managing by codes, protocols and so forth, could be used as a driving force to broaden the mind-set of decision makers and operators engaged in daily processes in cultural terms.

As argued by the Stakeholder Theory [40], an inexorable change in the governance approach of organizations in general has been started that needs to involve the healthcare sector. This implies a profound rethinking of management models, only minimally in place by most organizations.

From our perspective, action carried out in a logic, albeit broad, of accountability concerning new categories of stakeholders or new expectations of existing stakeholders, are not an expression of a real and complete transition towards sustainability. They are however, certainly signs of a progressive approach, the result of growing awareness but often stop there, thus delaying the completion of change of a paradigmatic nature.

It is in a harmonious vision of relations with the wider economic, social and environmental context that sustainability, as the highest evidence of achieved consonance, is realized [51,87-90]. This is a radical change in the way of conceiving organizations in general and the relationship with the environment understood in its entirety. Change is even more necessary, if not fundamental, in healthcare organizations in which sustainability becomes central to the paradigm of healthcare governance action. Organizations in general and healthcare organizations in particular-the object of our study, in essence, have to consider sustainability as the primary condition of viable survival, linking its success to that of its interlocutors in 'more than zero' sum game scheme. In other words, a sustainable but also inclusive organization whose focus is on creating contextual conditions for sustainability that generate widespread prosperity.

By reconciling efficiency and effectiveness through the bridge of sustainability [14,51,52], the concept of appropriateness of the healthcare service extends from a cost/benefit relation to a more complex evaluation of sustainability. Analysis should first examine how much deliverable care is expected to benefit patients and subsequently whether and in what way care could be provided less expensively. A further factor concerns the overall impact of the organization on the equilibrium of the ecosystem of the territorial context [91,92]. In this sense, the risk of inappropriateness can affect the system's stability also in sustainability terms, thus requiring a systems viability monitoring process that includes the evaluation of sustainability $[30,61,93]$.

Accordingly, in the case of conditions that cannot be recorded in the revenue statement, or health policies consistent with the expectations of the supra-systems, if not quantified by stringent economic 
criteria, control and verification of congruity with the systemic aims of the organization is required. In the planning of control, it is necessary to consider the systemic aspect that tends to seek the desired resonance between the objectives of the individual citizen-user (social legitimization of the existence of the healthcare company) and the objectives of the organization [20]. In the light of the VSA we propose, integrated control does not refer exclusively to the preparation of plans, budgets, calculation of costs and detection of deviations but also at the same time, the rationalization of information resources to guarantee balance and therefore sustainability through the exploitation of conditions of flexibility.

In particular, operators' attention to the use of resources does not only mean a tendency to reduce costs but also to monitor "significant oversights" that may influence government decisions and the relative service provision. Aspects such as quality, response times, environmental conditions, ease of access, the humanization of the service refer to a search for adequate budget determination and not necessarily to a tendency to contain it. Therefore, control impacts on the supra-systems of the healthcare organization, favouring the abandonment of structural control mechanisms.

Management control has to be conceived as an information system based on the choice of indicators able to measure, together with economic and financial variables, aspects such as customer satisfaction for the citizen-user, in order to analyse and diagnose the internal processes and their consistency with the objectives of the corporate mission as components of the overall national healthcare system, as well as to measure the growth prospects of the organization in co-evolution with the context as a whole.

Hence, in the planning of control it is necessary to consider the inter-systemic aspect that tends to seek the desired resonance between the objectives of the individual citizen-user (social legitimization of the existence of the healthcare organization), the objectives of the organization and the expectation of relevant stakeholders (supra-systems) up to the wider ecosystem context [20,94].

The concrete possibility that a healthcare organization will achieve this extended vision in terms of space and time depends, however, on the evaluation of the supra-systems identified as relevant in the context, carried out by the decision maker responsible for the governance and management of the healthcare organization.

An issue for reflection is how, at a more practical level, sustainability should be incorporated within healthcare management/control systems. It could be induced 'from outside' (top-down supra-systems' action), for example, through a system of incentives, when sustainability is not recognized by the organization as a value and sustainable action not practiced spontaneously in its operations. Obviously, in the event, sustainability was widely considered a shared 'value'-such incentives would not be necessary as undoubtedly self-regulation would be the norm.

In any case, it must be stressed that being sustainable by being committed to sustainability, is not sufficient even if consistency would require being sustainable as a prerequisite for commitment to sustainability. In contrast, the promotion of sustainable development moves in a context in which the relative value seems more acknowledged in principle and in intentions rather than in practice [95-97].

\section{Conclusions}

Healthcare organizations are experiencing a period of great change and are engaged in redefining their organizational and management structure. This significant revision of the system is part of a broader process of modifying the functioning of the health sector in the main European countries.

Management control, if considered in its definition of method to support routine operative activity and not as a mere tool necessary to carry out formal verification of acts or single evaluation of operating costs, can provide considerable support for health administrators in dealing with the current period of radical change more effectively. In this context, control assumes values and meanings that range from organization, to control of economic-financial variables, to the definition of forecasts and, finally, to the monitoring system of viability for sustainability [56].

The limits of traditional management approaches are represented by the fact that it is not the increment in the volume of services that guarantees better overall health: on the contrary, this frequently 
ends up by inappropriately eroding resources, without rendering the results of healthcare measurable or verified.

Management and control tools should be rethought not in terms of quantitative aspects of production dynamics but of the overall effectiveness of healthcare action. In other words, they should not merely favour the maximization of volumes or reduction of costs per benefit but be oriented towards measurable health indicators. This implies a shift in process from the simple offer of services to integrated health management. Consequently, in short, we believe that future research directions should investigate on a well-structured and effective Information System that represents the necessary support for the governance and coordination functions of healthcare organizations as the basic condition for attributing responsibility to professional figures for management processes $[52,85,98]$ and for implementing a valid monitoring system of viability and sustainability (both structural adequacy of components and relationships and performance at both operational and systemic levels) [99-103].

In sum, from our viewpoint therefore, incorporating sustainability into management and control systems is a fundamental area to which the attention of policy makers, operators and scholars should be addressed. In the particular case of healthcare organizations, having the specific purpose of safeguarding health, sustainability is an aim fully compliant with current economic environmental global challenges [104-107].

Author Contributions: Conceptualization, M.S.; Methodology, C.B. and P.P.; Software, C.B.; Formal Analysis, C.B., P.P. and P.D.N.; Resources, M.L.; Data Curation, C.B. and M.L.; Writing-Original Draft Preparation, C.B. and P.D.N.; Writing-Review \& Editing, M.S., C.B. and a Native English Language Speaker; Supervision, M.S.; please turn to the CRediT taxonomy for the term explanation.

Funding: This research received no external funding

Conflicts of Interest: The authors declare no conflict of interest.

\section{References}

1. Barile, S. Introduzione. In Condizioni di Efficacia Relazionale e di Performance Nell'Azienda Sanitaria; Saviano, M., Ed.; Giappichelli: Torino, Italy, 2012.

2. Aquino, R.P.; Barile, S.; Grasso, A.; Saviano, M. Envisioning smart and sustainable healthcare: 3D Printing technologies for personalized medication. Futures 2018, 103, 35-50. [CrossRef]

3. Barile, S.; Saviano, M. Complexity and Sustainability in Management: Insights from a Systems Perspective. In Social dynamics in a Systems Perspective; Barile, S., Pellicano, M., Polese, F., Eds.; New Economic Window Book Series; Springer International: Cham, Switzerland, 2018; pp. 39-63.

4. Saviano, M. Multi-actor co-creation systems for progressing toward sustainability: Criticalities and challenges. In Proceedings of the 5th International Conference on Sustainability Science (ICSS), Tokyo, Japan, 22-23 January 2015.

5. Beer, S. Brain of the Firm: A Development in Management Cybernetics; Herder and Herder: New York, NY, USA, 1972.

6. Von Bertallanfy, L. General System Theory. Foundations, Development, Applications; Penguin University Books: New York, NY, USA, 1968.

7. Von Foerster, H. Observing Systems; Intersystems Publications: Seaside, CA, USA, 1984.

8. Polese, F.; Carrubbo, L.; Bruni, R.; Caputo, F. Enabling actors' viable behaviour: Reflections upon the link between viability and complexity within smart service system. Int. J. Mark. Bus. Syst. 2018, 3, 111-120. [CrossRef]

9. Kongstvedt, P.R. The Managed Healthcare Handbook; Jones \& Bartlett Learning: Burlington, MA, USA, 2001.

10. Kongstvedt, P.R. Managed Care: What It Is and How It Works; Jones \& Bartlett Learning: Burlington, MA, USA, 2002.

11. Borgonovi, E.; Compagni, A. Sustaining Universal Health Coverage: The Interaction of Social, Political, and Economic Sustainability. Value Health 2013, 16, S34-S38. [CrossRef] [PubMed]

12. Adinolfi, P.; Borgonovi, E. The Myths of Health Care Towards New Models of Leadership and Management in the Healthcare Sector; Springer: Berlin, Germany, 2018; ISBN 978-3-319-53600-2. 
13. Aquino, R.; Barile, S.; Grasso, A.; Saviano, M. Managing variety in healthcare through personalized medication: The contribution of 3D-printing technologies. In Cybernetics and Systems. Social and Business Decisions; Barile, S., Espejo, R., Perko, I., Saviano, M., Eds.; Systems Management Book Series; Giappichelli-Routledge: London, UK, 2018; pp. 345-350.

14. Golinelli, G.M. Viable Systems Approach (VSA). Governing Business Dynamics; Cedam, Wolters Kluwer Italia Srl: Lavis (TN), Italy, 2010.

15. Barile, S. L'Impresa Come Sistema. Contributi Sull'Approccio Sistemico Vitale, 2nd ed.; Giappichelli: Torino, Italy, 2008.

16. Porter, M.E.; Kramer, M.R. Creating shared value. Harv. Bus. Rev. 2011, 89, 62-77.

17. Pels, J.; Kidd, T. Characterizing emerging markets. Organ. Mark. Emerg. Econ. 2012, 3, 8-22.

18. Gebauer, H.; Reynoso, J. An agenda for service research at the base of the pyramid. J Serv. Manag. 2013, 24, 482-502. [CrossRef]

19. Pels, J.; Barile, S.; Saviano, M.; Polese, F.; Carrubbo, L. The contribution of VSA and SDL perspectives to strategic thinking in emerging economies. Manag. Serv. Qual. 2014, 24, 565-591. [CrossRef]

20. Saviano, M.; Barile, S.; Spohrer, J.C.; Caputo, F. A service research contribution to the global challenge of sustainability. J. Serv. Theory Pract. 2017, 27, 951-976. [CrossRef]

21. Saviano, M.; Nenci, L.; Caputo, F. The financial gap for woman in the MENA region: A systemic perspective. Gend. Manag. Int. J. 2017, 32, 203-217. [CrossRef]

22. Buchanan, D.A.; Fitzgerald, L.; Ketley, D. (Eds.) The Sustainability and Spread of Organizational Change: Modernizing Healthcare; Routledge: London, UK, 2006.

23. Cappelletti, P. The future of Healthcare: Financial sustainability and possible scenarios. Ital. J. Lab. Med. 2012, 8, 63-70. [CrossRef]

24. Cohen, D.; McDaniel, R.R., Jr.; Crabtree, B.F.; Ruhe, M.C. A practice change model for quality improvement in primary care practice. J. Healthc. Manag. 2004, 49, 155. [CrossRef] [PubMed]

25. Franche, R.L.; Cullen, K.; Clarke, J.; Irvin, E.; Sinclair, S.; Frank, J. Institute for Work \& Health (IWH) Workplace-Based RTW Intervention Literature Review Research Team. Workplace-based return-to-work interventions: A systematic review of the quantitative literature. J. Occup. Rehabil. 2005, 15, 607-631. [PubMed]

26. Janssen, M.; Moors, E.H. Caring for healthcare entrepreneurs-Toward successful entrepreneurial strategies for sustainable innovations in Dutch healthcare. Technol. Forecast. Soc. Chang. 2013, 80, 1360-1374. [CrossRef]

27. Farioli, F.; Barile, S.; Saviano, M.; Iandolo, F. Re-reading sustainability through the Triple Helix model in the frame of a systems perspective. In The Sage Handbook of Nature; Marsden, T., Ed.; SAGE: London, UK, 2018; pp. 10-37. ISBN 9781526421951.

28. Scalia, M.; Barile, S.; Saviano, M.; Farioli, F. Governance for Sustainability: A triple Helix Model. Sustain. Sci. 2018, 13, 1235-1244. [CrossRef]

29. Bebbington, J.; Unerman, J.; O’Dwyer, B. Sustainability Accounting and Accountability; Routledge: London, UK, 2014.

30. Saviano, M.; Bassano, C.; Calabrese, M. A VSA-SS Approach to Healthcare Service Systems. The Triple Target of Efficiency, Effectiveness and Sustainability. Serv. Sci. 2010, II, 41-61. [CrossRef]

31. Barile, S. Contributi sul Pensiero Sistemico; Arnia: Salerno, Italy, 2000.

32. Golinelli, G.M. L'Approccio Sistemico al Governo Dell'Impresa. L'Impresa Sistema Vitale, $1^{\mathrm{a}}$ ed.; Cedam: Padova, Italy, 2000; Volume I.

33. Golinelli, G.M. L'Approccio Sistemico al Governo Dell'Impresa. Valorizzazione Delle Capacità, Rapporti Intersistemici e Rischio Nell'Azione di Governo, $1^{\mathrm{a}}$ ed.; Cedam: Padova, Italy, 2002; Volume III.

34. Golinelli, G.M. L'Approccio Sistemico al Governo Dell'Impresa. L'Impresa Sistema Vitale, 2a ed.; Cedam: Padova, Italy, 2005; Volume I.

35. Barile, S. Management Sistemico Vitale. Decidere in Contesti Complessi; Giappichelli Editore: Torino, Italy, 2009.

36. Barile, S.; Saviano, M. Foundations of systems thinking: The structure-systems paradigm. In Contributions to Theoretical and Practical Advances in Management. A Viable Systems Approach (vSA); ASvSA-Associazione per la Ricerca sui Sistemi Vitali; International Printing: Avellino, Italy, 2011; pp. 1-25. 
37. Saviano, M.; Parida, R.; Caputo, F.; Datta, S.K. Insights on Italian and Indian health care systems from VSA perspective. In 6th Annual EuroMed Conference of the EuroMed Academy "Confronting Contemporary Business Challenges through Management Innovation"; Vrontis, D., Weber, Y., Tsoukatos, E., Eds.; EuroMed Press: Nicosia, Cyprus, 2013; pp. 1586-1603. ISBN 978-9963-711-16-1.

38. Barile, S.; Pellicano, M.; Polese, F. Social Dynamics in a Systems Perspective; New Economic Window Book Series; Springer International: Cham, Switzerland, 2018.

39. Barile, S.; Saviano, M.; Iandolo, F.; Calabrese, M. The Viable Systems Approach and its Contribution to the Analysis of Sustainable Business Behaviors. Syst. Res. Behav. Sci. 2014, 31, 683-695. [CrossRef]

40. Freeman, E. Strategic Management: A Stakeholder Approach; Pitman series in Business and Public Policy; Harpercollins College Div: Marshfield, MA, USA, 1984.

41. Badinelli, R.; Barile, S.; NG, I.; Polese, F.; Saviano, M.; Di Nauta, P. Viable service systems and decision making in service management. J. Serv. Manag. 2012, 23, 498-526. [CrossRef]

42. Calabrese, M.; Iandolo, F.; Caputo, F.; Sarno, D. From mechanical to cognitive view: The changes in decision making in a business environment. In Social Dynamics in a System Perspective; Barile, S., Pellicano, M., Polese, F., Eds.; Springer: New York, NY, USA, 2018; pp. 223-240.

43. Tronvoll, B.; Barile, S.; Caputo, F. A systems approach to understanding the philosophical foundation of marketing studies. In Social Dynamics in a System Perspective; Barile, S., Pellicano, M., Polese, F., Eds.; Springer: New York, NY, USA, 2018; pp. 1-18.

44. Barile, S.; Lusch, R.; Reynoso, J.; Saviano, M.; Spohrer, J. Systems, Networks, and Eco-systems in Service Research. J. Serv. Manag. 2016, 27, 652-674. [CrossRef]

45. Paniccia, P.M.A.; Leoni, L.; Baiocco, S. Interpreting Sustainability through co-evolution: Evidence from Religious accommodation in Rome. Sustainability 2017, 9, 12. [CrossRef]

46. Piciocchi, P.; Bassano, C.; Galvin, M. Rethinking the concept of Ethics for Public Corporate Identity. In Advances in the Human Side of Service Engineering; Freund, L., Cellary, W., Eds.; AHFE Conference Books; Springer: Berlin, Germany, 2014; pp. 3435-3440. ISBN 978-1-4951-2091-6.

47. Beer, S. Diagnosing the System for Organizations; John Wiley: London, UK; New York, NY, USA, 1985.

48. Bassano, C.; Ciasullo, M.V.; Gaeta, M.; Rarità, L. A Consensus-based Approach for Team Allocations: The Case of Logistics in Campania Region. CSIMQ 2016, 6, 12-30. [CrossRef]

49. Golinelli, G.M.; Bassano, C. Human resources for governing business dynamics. The Viable Systems Approach. In Advances in the Human Side of Service Engineering; Spohrer, J.C., Freund, L., Eds.; Taylor \& Francis Ltd. (CRC Press): Boca Raton, FL, USA, 2012; pp. 359-368. ISBN 9781439870266.

50. London, T.; Hart, S.L. Reinventing strategies for emerging markets: Beyond the transnational model. J. Int. Bus. Stud. 2004, 35, 350-370. [CrossRef]

51. Golinelli, G.M.; Volpe, L. Consonanza, Valore, Sostenibilità: Verso L'Impresa Sostenibile; Cedam: Padova, Italy, 2012.

52. Piciocchi, P.; Bassano, C.; Paduano, E.; Galvin, M. The Viable Systems Approach (VSA) for re-interpreting network business dynamics. In Lecture Notes in Business Information Processing (LNBIP). Perspectives in Business Informatics Research; Grabis, J., Kirkova, M., Eds.; Springer: Berlin/Heidelberg, Germany, 2011; pp. 304-320. ISBN 9783642245107.

53. Barile, S.; Saviano, M. Elementi di qualificazione del pensierosistemico. In Contributi sul Pensiero Sistemico in Economia D'Impresa; Barile, S., Ed.; WM Stampa Editoriale Srl: Atripalda, Italy, 2000; Volume 18.

54. ASVSA. Available online: www.asvsa.org (accessed on 20 August 2018).

55. Adam, W.M. The Future of Sustainability: Re-Thinking Environment and Development in the Twenty-First Century; Report of the IUCN Renowned Thinkers Meeting; IUCN: Zurich, Switzerland, 2006.

56. Gibson, R.B. Beyond the pillars: Sustainability assessment as a framework for effective integration of social, economic and ecological considerations in significant decision-making. J. Envrion. Assess. Policy Manag. 2006, 8, 259-280. [CrossRef]

57. Daly, H. Ecological economics: The concept of scale and its relation to allocation, distribution, and uneconomic growth. In Ecological Economics and Sustainable Development: Selected Essays of Herman Daly; Daly, H., Ed.; Edward Elgar Publishing: Cheltenham, UK, 2007; pp. 82-103.

58. Barile, S.; Orecchini, F.; Saviano, M.; Farioli, F. People, technology, and governance for sustainability: The contribution of system and cyber-systemic thinking. Sustain. Sci. 2018, 13, 1197-1208. [CrossRef] 
59. Siano, A.; Conte, F.; Amabile, S.; Vollero, A.; Piciocchi, P. Communicating Sustainability: An Operational Model for Evaluating Corporate Websites Sustainability. Sustainability 2016, 8, 950. [CrossRef]

60. Saviano, M. Il valore culturale del patrimonio naturale nella promozione dello sviluppo sostenibile. Sinerg. Ital. J. Manag. 2016, 34, 167-194.

61. Piciocchi, P. Crisi D'Impresa e Monitoraggio di Vitalità. L'Approccio Sistemico Vitale per L'Analisi dei Processi di Crisi; Giappichelli: Torino, Italy, 2003.

62. Kirikova, M.; Piciocchi, P.; Bassano, C.; Makna, J.; Stecjuka, J. Managing Change in Fractal Enterprises and IS architectures from a Viable Systems Perspective. In Lecture Notes in Business Information Processing (LNBIP). Perspectives in Business Informatics Research; Niedrite, L., Strazdina, R., Wangler, B., Eds.; Springer: Berlin/Heidelberg, Germany, 2012; Volume 106, pp. 38-50.

63. Kessler, M.M. Bibliographic coupling between scientific papers. Am. Doc. 1963, 14, 10-25. [CrossRef]

64. Waring, J.; Currie, G. Managing expert knowledge: Organizational challenges and managerial futures for the UK medical profession. Organ. Stud. 2009, 30, 755-778. [CrossRef]

65. Numerato, D.; Salvatore, D.; Fattore, G. The impact of management on medical professionalism: A review. Sociol. Health Illn. 2012, 34, 626-644. [CrossRef] [PubMed]

66. Longo, F.; Salvatore, D.; Tasselli, S. Are public health authorities able to "steer" rather than "row"? An empirical analysis in the Italian National Health Service. Int. J. Health Plan. Manag. 2011, 26, 319-333. [CrossRef] [PubMed]

67. Kraus, K.; Kennergren, C.; von Unge, A. The interplay between ideological control and formal management control systems-A case study of a non-governmental organisation. Account. Organ. Soc. 2017, 63, 42-59. [CrossRef]

68. Beil-Hildebrand, M.B. Theorising culture and culture in context: Institutional excellence and control. Nurs. Inq. 2002, 9, 257-274. [CrossRef] [PubMed]

69. Cooke, H. Out there, you're on a stage": Complaints and the management of emotion work in nursing. Int. J. Work Organ. Emot. 2007, 2, 145-160.

70. Houghton, F. Reflection and comment: Health GIS in the mid-west: Unexpected developments and directions. Ir. Geogr. 2006, 39, 99-104. [CrossRef]

71. Wise, S.; Duffield, C.; Fry, M.; Roche, M. Workforce flexibility-In defence of professional healthcare work. J. Health Organ. Manag. 2017, 31, 503-516. [CrossRef] [PubMed]

72. Monfardini, P.; Ruggiero, P.; Gepponi, A.; Barretta, D. Inter-organizational management control in Health and Social Care: An exploratory analysis of Healthcare Consortia in Tuscany. Mecosan 2009, 71, 85-98.

73. Elg, M.; Stenberg, J.; Kammerlind, P.; Tullberg, S.; Olsson, J. Swedish healthcare management practices and quality improvement work: Development trends. Int. J. Health Care Qual. Assur. 2011, 24, 101-123. [CrossRef] [PubMed]

74. Vaia, G.; Bisogno, M.; Bizzarri, G. How to Drive Innovation Within Outsourcing Relations: The Role of Performance Evaluation and Management Control Systems. In International Workshop on Global Sourcing of Information Technology and Business Processes; Springer: Cham, Switzerland, 2015; pp. 142-155.

75. King, R.; Clarkson, P. Management control system design, ownership, and performance in professional service organisations. Account. Organ. Soc. 2015, 45, 24-39. [CrossRef]

76. Lunkes, R.J.; Naranjo-Gil, D.; Lopez-Valeiras, E. Management Control Systems and Clinical Experience of Managers in Public Hospitals. Int. J. Environ. Res. Public Health 2018, 15, 776. [CrossRef] [PubMed]

77. Naranjo-Gil, D.; Sánchez-Expósito, M.J.; Gómez-Ruiz, L. Traditional vs. Contemporary management control practices for developing public health policies. Int. J. Environ. Res. Public Health 2016, 13, 713. [CrossRef] [PubMed]

78. Naranjo, D.G. The use of the balanced scorecard and the budget in the strategic management of public hospitals. Gac. Sanit. 2010, 24, 220-224.

79. Morelli, M.; Lecci, F. Governo dei costi e cambiamento aziendale. La lunga strada verso l'integrazione. Mecosan 2011, 20, 59-75.

80. Morelli, M.; Lecci, F. Management control systems (MCS) change and the impact of top management characteristics: The case of healthcare organisations. J. Manag. Control 2014, 24, 267-298. [CrossRef]

81. Willemstein, P.; van der Vem, M.; Versendaal, J. Professionalizing management accounting and control at small healthcare organizations: A case study. In Proceedings of the 7th IADIS International Conference Information Systems, Madrid, Spain, 28 February-2 March 2014. 
82. Rouhana, R.; Van Caillie, D. The design of performance monitoring systems in healthcare organizations: A stakeholder perspective. J. Med. Liban. 2016, 64, 270-279.

83. Pinzone, M.; Lettieri, E.; Masella, C. Sustainability in healthcare: Combining organizational and architectural levers. Int. J. Eng. Bus. Manag. 2012, 4, 4-38. [CrossRef]

84. Swanepoel, D.W.; Clark, J.L.; Koekemoer, D.; Hall, J.W., III; Krumm, M.; Ferrari, D.V.; McPherson, B.; Olusanya, B.O.; Mars, M.; Russo, I.; et al. Telehealth in audiology: The need and potential to reach under served communities. Int. J. Audiol. 2010, 49, 195-202. [CrossRef] [PubMed]

85. Bassano, C. Il Controllo di Gestione Nelle ASL. Strumenti di Controllo Strutturale e Sistemico. Ph.D. Thesis, Salerno Univeristy, Fisciano, Italy, 2004.

86. Barile, S.; Farioli, F.; Orecchini, F.; Saviano, M. Is a smarter planet also more sustainable? Co-creating knowledge for sustainability. In Cybernetics and Systems. Social and Business Decisions; Barile, S., Espejo, R., Perko, I., Saviano, M., Eds.; Systems Management Book Series; Giappichelli-Routledge: London, UK, 2018; in press.

87. Clayton, T.; Radcliffe, N. Sustainability: A Systems Approach; Routledge: London, UK, 2015.

88. Bosch, O.J.H.; Nguyen, N.C.; Ha, T.M. Can advancements in economic and managerial practice be achieved without systems thinking education as the foundation. Bus. Syst. Rev. 2014, 3, 33-53.

89. Barile, S.; Espejo, R.; Perko, I.; Saviano, M. Cybernetics and Systems. Social and Business Decisions; Systems Management Book Series; Giappichelli-Routledge: London, UK, 2018; ISBN 978-1-138.

90. Maggioni, V. Una rimeditazione dei rapporti tra profitto e valore alla ricerca di una consonanza intersistemica. Sinerg. Ital. J. Manag. 2011, 81, 117-134.

91. Sciarelli, F.; Rinaldi, A. Development Programmes in Asia. In Development Management of Transforming Economies; Sciarelli, F., Rinaldi, A., Eds.; Palgrave Macmillan: London, UK, 2017; pp. 269-355.

92. Nidumolu, R.; Prahalad, C.K.; Rangaswami, M.R. Why sustainability is now the key driver of innovation. Harv. Bus. Rev. 2009, 87, 56-64.

93. Hysa, X.; Zerba, E.; Calabrese, M.; Bassano, C. Social business as a sustainable business model: Making capitalism antifragile. Sustain. Sci. 2018, 13, 1345-1356. [CrossRef]

94. Bassano, C.; Carotenuto, A.; Ferretti, M.; Pietronudo, M.C.; Coşkun, H.E. Smart University for sustainable governance in smart local service systems. In Advances in Intelligent Systems and Computing (AISC); Ahram, T.Z., Ed.; Springer: Berlin, Germany, 2019; ISBN 978-3-319-94228-5, 978-3-319-94229-2.

95. Pencarelli, T.; Cerquetti, M.; Splendiani, S. The sustainable management of museum: An Italian perspective. Tour. Hosp. Manag. 2016, 22, 29-46. [CrossRef]

96. Di Nauta, P.; Sarno, D. Possono le pratiche di value co-creation contribuire allo sviluppo di un ecosistema sanitario efficace? Prospett. Organ. ASSIOA 2017, 7, 1-9.

97. Saviano, M. Condizioni di Efficacia Relazionale e di Performance Nell'Azienda Sanitaria; Saviano, M., Ed.; Giappichelli: Torino, Italy, 2012.

98. Spohrer, J.; Piciocchi, P.; Bassano, C. Three Frameworks for Service Research: Exploring Multilevel Governance in Nested, Networked Systems. Serv. Sci. 2012, 4, 147-160. [CrossRef]

99. Spohrer, J.; Piciocchi, P.; Bassano, C.; Giuiusa, A. Smart Governance to mediate human expectations and systems context interactions. In Advances in the Human Side of Service Engineering; Spohrer, J.C., Freund, L., Eds.; Taylor \& Francis Ltd. (CRC Press): Boca Raton, FL, USA, 2012; pp. 319-328. ISBN 9781439870266.

100. Srivastava, R. The Healthcare Professional's Guide to Clinical Cultural Competence; Elsevier Health Sciences: Amsterdam, The Netherlands, 2007.

101. Barile, S.; Quattrociocchi, B.; Calabrese, M.; Iandolo, F. Sustainability and the Viable Systems Approach: Opportunities and Issues for the Governance of the Territory. Sustainability 2018, 10, 790. [CrossRef]

102. Polese, F.; Di Nauta, P. A Viable Systems Approach to Relationship Management in S-D Logic and Service Science. Die Betriebswirtschaft. Schäffer-Poeschel Verlagfür Wirtschaft.Steuern·Recht GmbH 2013, 73, 113-129.

103. Aguiari, R.; Di Nauta, P. Governing business dynamics in complex contexts. Mercat. Compet. 2012, 39-59. [CrossRef]

104. Reina, R.; Martinez, M.; Di Nauta, P.; Merola, B. The organizational space in Health: The mApp as a sustainable knowledge creation process. In Cybernetics and Systems. Social and Business Decisions; Barile, S., Espejo, R., Perko, I., Saviano, M., Eds.; Systems Management Book Series; Giappichelli-Routledge: London, UK, 2018; pp. 175-180. ISBN 9781138597280. 
105. Carrubbo, L.; Di Nauta, P.; Moretta Tartaglione, A. A2A Relationships in Service Contexts. Chin. Bus. Rev. 2012, 11, 873-890.

106. Reynoso, J.; Barile, S.; Saviano, M.; Spohrer, J. Service Systems, Networks and Ecosystems: Connecting the Dots Concisely from a Systems Perspective. In Handbook of Service-Dominant Logic; Vargo, S.L., Lusch, R.F., Eds.; The SAGE: Newcastle Upon Tyne, UK, 2018; ISBN 9781526402837.

107. Barile, S.; Saviano, M.; Polese, F. Information asymmetry and co-creation in health care services. Australas. Mark. J. 2014, 22, 205-217. [CrossRef] 